\title{
Vermiculture as a source of animal protein
}

\author{
Elena Antonova ${ }^{1, *}$, Igor Titov $^{2}$, Irina Pashkova ${ }^{1}$, and Devard Stom ${ }^{1}$ \\ ${ }^{1}$ Irkutsk state university, 664003 Irkutsk, Russia \\ ${ }^{2}$ Vladimir state university, 600026 Vladimir, Russia
}

\begin{abstract}
The paper presents a data analysis of the international scientific community on the issues of vermicultivation for the last 75 years. The authors considered terminology, the biochemical contents of earthworms' tissues, production technology; distinguished 4 stages, 8 methods and biological aspects of their safety. The paper covers economic production characteristics. The results on the practical use of dry and paste vermiproducts have been summarized: feed additives in fishing (6 examples), poultry farming (8 examples), mammal breeding (3 examples), growth media for microorganisms (1 example). The benefits of vermiproducts as food supplements for humans have been explored. Vermi food contains a high amount of protein (64.5-72.9\% per dry weight), all essential amino- and fatty acids, calcium (cheese and milk), iron (10 times more than in soybeans).
\end{abstract}

\section{Introduction}

At present, animal protein is becoming an increasingly valuable resource of food and livestock industries. There are a number of studies aimed at searching for alternative sources of protein. One of the most promising is the use of earthworms' biomass. However, studies in this area are fragmented.

Lawrence and Millar (1945) were the first to focus on getting additional source of protein from vermiculture (Lumbricus rubellus). Earthworms contain $62.0-71.5 \%$ of total animal protein and $1.5 \%$ of total fat per dry weight. Earthworm protein in addition includes "all amino acids obtained in the process of animal tissues hydrolysis".

Scientific research conducted in the USA and Great Britain proved that some species of earthworms (Eisenia fetida, Eisenia andrei, Perionyx excavatus, Eudrilus eugeniae $u$ Dendrobaena veneta) can be used not only for organic waste recycling but also as a renewable resource of high-quality fodder premixes.

McInroy's first scientific work in 1971 laid a foundation for numerous chemical and biochemical research of different earthworms' tissues components in a number of countries such as the USA, Great Britain, Germany, China, the Philippines, Japan, India, etc. The methods were developed to obtain dry and paste protein samples and tests were carried out to use them as combined feed.

\footnotetext{
${ }^{*}$ Corresponding author: antoshki05@rambler.ru
} 
The principal aim of the work is the analyses of biotechnology concerning obtaining animal protein from vermiculture and also its feed nutritional value.

\section{Materials and methods}

The article presents the review and analysis of 67 scientific research works on the problem of vermicultivation and the use vermiproducts for the last 75 years.

\section{Results and discussion}

In scientific literature the term "earthworm protein" means the total content of all protein, peptide and free amino acids in earthworms' tissues. It is very difficult to estimate this parameter even after dealing with its full genomic DNA Lumbricus rubellus (18.000 genes encoding proteins).

Compost from earthworms or vermicompost is raw eathworms' biomass processed into dry protein powder. You can come across such terms as vermitine, vermitein, vermiprotein (from Latin "verme" meaning worms and from English "protein") in English literature.

The biochemical contents of earthworms' tissues do not differ significantly from vertebrate tissues. Protein and amino acid content in vermipowder from Eisenia fetida and Eudrilus eugeniae is similar to fish meal that is used to feed livestock.

Vermipowder corresponds to the standards for high-quality animal feed recommended by the Food and Agriculture Organization and the World Health Organization according to the essential amino acids content (table 1).

The most important ingredient of animal feed is amino acid lysine and also the combination of amino acids - methionine-cysteine and phenylalanine-tyrosine. All earthworms' tissues contain lysine (4.95-5.70 gr/100 gr protein) and methionine (2.08-2.30 gr/100 gr protein).

Dedekte and his collegues (2010) [1] determined the amino acid content of 4 earthworm species (Eudrilus eugeniae, Hyperio drilusafricanus, Almamill soni, Libyodrilus violaceus). They identified cysterine content (0.64-0.80 gr/100 gr protein) and glutamic acid content (11.50-13.22 gr/100 gr).

In addition, earthworms' tissues contain substantial amounts of long-chain fatty acids. This fact is of great importance as animals without a paunch cannot synthesize indispensable compounds.

Table 1. Earthworms' tissues content

\begin{tabular}{|c|c|c|c|c|c|}
\hline \multirow{2}{*}{$\begin{array}{l}\text { nutritional and } \\
\text { energy value }\end{array}$} & \multirow[b]{2}{*}{ content } & \multicolumn{4}{|c|}{ Essential amino acids, g/100 g biomass } \\
\hline & & name & $\begin{array}{l}\text { FAO and WHO } \\
\text { recommendations }\end{array}$ & earthworms & $\begin{array}{c}\text { fish } \\
\text { meal }\end{array}$ \\
\hline \multicolumn{2}{|l|}{ Nutritional Value: } & arginine & - & 6.0 & 3.9 \\
\hline water & $78-88 \%$ & cysteine & 2,0 & 1.5 & 0.8 \\
\hline protein & $60-70 \%$ & histidin & - & 2.6 & 1.5 \\
\hline fat & $6-12 \%$ & isoleucine & $4.0-4.2$ & 4.3 & 3.6 \\
\hline carbohydrates & $5-21 \%$ & leucine & $4.8-7.0$ & 7.2 & 5.1 \\
\hline mineral substances & $2-3 \%$ & lysine & $4.2-6.5$ & 6.8 & 6.4 \\
\hline vitamins & $358 \mathrm{mg} / \mathrm{kg}$ & methionine & 2.2 & 2.0 & 1.8 \\
\hline \multirow{5}{*}{ energy value } & \multirow{5}{*}{$24 \mathrm{~kJ} / \mathrm{g}$} & phenylalanine & 2.8 & 3.8 & 2.6 \\
\hline & & threonine & $2.8-4.0$ & 5.2 & 2.8 \\
\hline & & triptophane & $1.0-1.4$ & 1.4 & - \\
\hline & & tyrosine & 2.8 & 3.2 & 1.8 \\
\hline & & valine & $4.2-5.1$ & 4.7 & 3.5 \\
\hline
\end{tabular}


Table 2. Earthworms' tissues content: mineral substances and vitamins

\begin{tabular}{|c|c|c|c|}
\hline \multicolumn{2}{|c|}{ mineral substances } & \multicolumn{2}{c|}{ vitamins } \\
\hline name & content & name & content \\
\hline calcium & $1.49 \%$ & niacin & $358 \mathrm{ug} / \mathrm{g}$ \\
\hline phosphorus & $0.89 \%$ & riboflavin $\left(\mathrm{B}_{2}\right)$ & $147 \mathrm{ug} / \mathrm{g}$ \\
\hline magnesium & $0.16 \%$ & panthothenic acid $(\mathrm{B}$ complex $)$ & $16 \mathrm{ug} / \mathrm{g}$ \\
\hline iron & $0.13 \%$ & thiamin $\left(\mathrm{B}_{1}\right)$ & $15 \mathrm{ug} / \mathrm{g}$ \\
\hline copper & $7.83 \mathrm{ug} / \mathrm{g}$ & pyridoxin $\left(\mathrm{B}_{6}\right)$ & $2 \mathrm{ug} / \mathrm{g}$ \\
\hline zink & $122.5 \mathrm{ug} / \mathrm{g}$ & vitamin $\mathrm{B}_{12}$ & $4 \mathrm{ug} / \mathrm{g}$ \\
\hline cadmium & $21.0 \mathrm{ug} / \mathrm{g}$ & folic acid & $0.5 \mathrm{ug} / \mathrm{g}$ \\
\hline
\end{tabular}

\subsection{Vermicompost production technology}

Vermicompost production technology consists of 4 stages: earthworms' raising; earthworms'gathering (separating from the substrate); earthworms' processing into vermipowder (paste-like products); packaging and storage of vermipowder.

\subsubsection{Earthworms' raising}

Earthworms Eisenia fetida are the best choice to produce animal protein as they have a shorter breeding season, they are highly productive and occur in the environments with a high content of organic material. The use of larger species of earthworms that gain weight quickly such as the Belgian worm Dendrobeana veneta (in temperate climates) and the African worm Eudrilus eugeniae (in the tropics) is considered promising.

Different industrial facilities are widely used in Russia to raise the worm Eisenia fetida but hardly anyone produces vermipowder.

The classic sigmoidal curve describes the growth patterns and breeding population of some worm species [2]. Maximum protein content is gained by inoculation of large amounts of organic containing waste and a relatively small number of earthworms. However, there is an opportunity of simultaneously producing both vermicompost and earthworms' biomass in the same system of vermicomposting.

The levels of bioconversion of organic waste in the process of vermicomposting into biomass of earthworms include: dung and swine manure $-10 \%$, horse manure $-7 \%$, active silt $-6 \%$, poultry manure $-5 \%$, potato peel waste and sewage sludge $-4 \%$ [3]

\subsubsection{Earthworm gathering}

The separation of earthworms from the substrate.

The optimal substrate moisture in the process of vermiculture is $80-90 \%$. The use of mechanical ways of separation (a sieve with the certain diameter of meshes) requires substrate pre-drying (maximum acceptable humidity $52 \%$, otherwise meshes are blocked). Most manufacturers growing large worms prefer collecting them by hand.

There has been developed a technology of selecting earthworms and their cocoons cultivated in the substrate, e.g. in sand with the particle diameter no more than 1 millimeter [4]. Extracts of plants are used as nutrient supply, aqueous extract of water pepper (Polugonnum hydropiper) is used to collect earthworms. Separating cocoons from the substrate is done by its being passed through a sieve with a mesh of no more than $2 \mathrm{~mm}$. Earthworms' gathering without separating from the substrate.

Professor Sun from China agricultural university in Beijing was the first to offer the use of vermicompost as an ingredient of animal feed (Sun, 1995, 2004). Earthworm coprolites contain $3.43 \%$ of humus substance, $0.184 \%$ of total nitrogen, $0.248 \%$ of total phosphorus 
and $29.93 \%$ of organic matter (Sun, 2003). They have $7.9 \%$ (per dry matter) of total protein that can be compared with corn meal. The amount of amino acids in earthworm coprolites is lower than in wheat middling. Nevertheless, earthworm coprolites contain more essential amino acids (lysine, methionine, isoleucine) than wheat middling and corn meal. However, earthworm coprolites have low nutritional value. In this research earthworms Eisenia fetida $(5 \%)$ were mixed with wheat middling and dry worm castings $(8 \%)$. This feed mix proved to be extremely efficient as the substitution of fishmeal in the laying hen diet.

Russia has experience in making protein and vitamin animal feed from earthworms' biomass raised on wastes from food processing. The preparation consists of vermipowder $60-65 \%$, vermipowder from apple pomace - 40-35\% [5].

\subsubsection{Earthworms' processing into vermipowder}

\section{Removing impurities.}

Raised earthworms have different substrate impurities left on their bodies and undigested waste in their digestive system. Therefore, it is necessary to wash earthworms in clean running water. Earthworms are left in water for at least 8 hours to get rid of internal contamination [2].

\section{Making protein preparations (table 2).}

Six methods of earthworms' processing have been developed under the guidance of Professor Clive Edwards at Ohio University (the USA) to make paste-like products and powder [2].

The choice of the method of earthworms' biomass processing depends on a number of things: the type of animal feed, its production costs, minimum dry matter and water-soluble nutrients loss.

Table 2. Production methods of protein preparations from earthworms

\begin{tabular}{|c|c|}
\hline Method & Description \\
\hline blanching & $\begin{array}{l}\text { blanching earthworms in boiling water for } 1 \text { min, then incorporating them in } 30 \% \\
\text { molasses together with } 0.3 \% \text { potassium sorbate to produce a paste - vermipaste that can be } \\
\text { stored very long at room temperature as molasses and potassium sorbate decrease the } \\
\text { activity of water }\left(\mathrm{A}_{\mathrm{w}}\right) 0.90 \text { and } 0.65 \text { respectively, the growth of yeasts and molds is inhibited }\end{array}$ \\
\hline $\begin{array}{c}\text { formic acid } \\
\text { treatment }\end{array}$ & $\begin{array}{l}\text { incorporation of } 3 \% \text { formic acid with the earthworms with thorough homogenization to } \\
\text { produce a very stable paste or liquid product }\end{array}$ \\
\hline \multirow{4}{*}{$\begin{array}{c}\text { making dry } \\
\text { vermipowder }\end{array}$} & $\begin{array}{l}\text { blanching earthworms in boiling water for } 1 \mathrm{~min} \text {, then drying and grinding are performed to } \\
\text { make powder }\end{array}$ \\
\hline & freezing earthworms quickly, then freeze-drying them and grinding them into powder \\
\hline & $\begin{array}{l}\text { killing earthworms in acetone for } 1 \text { hour, then over-drying them at } 95{ }^{\circ} \mathrm{C} \text { before grinding } \\
\text { them }\end{array}$ \\
\hline & $\begin{array}{l}\text { blanching earthworms in boiling water, then over-drying them at } 95{ }^{\circ} \mathrm{C} \text { before grinding } \\
\text { them }\end{array}$ \\
\hline $\begin{array}{l}\text { making vermi } \\
\text { protein } \\
\text { (Kuznetzov, } \\
\text { 2003) [6] }\end{array}$ & $\begin{array}{l}\text { homogenization of fat-free earthworm biomass, mixing with } 0.01-0.5 \% \text { alkali solution at a } \\
\text { mass ratio of } 1: 3-1: 11 \text {, protein extraction at the temperature of } 40-100{ }^{\circ} \mathrm{C} \text { continuously } \\
\text { stirring for } 10-60 \mathrm{~min} \text {, removing undissolved components, precipitation of protein at an } \\
\text { isoelectric point. } \\
\text { The product contains } 78-93 \% \text { of vermin protein and } 46.5-48.6 \% \text { of essential amino acids. }\end{array}$ \\
\hline $\begin{array}{l}\text { making } \\
\text { vermicompost } \\
\text { (Guerrero, } \\
\text { 2009) [7] }\end{array}$ & $\begin{array}{l}\text { placing earthworms into a water tank heated to the temperature to } 50-60{ }^{\circ} \mathrm{C} \text {, then air- or } \\
\text { oven-drying them at } 80-90{ }^{\circ} \mathrm{C} \text { to the maximum humidity of } 5 \% \text {, grinding them into } \\
\text { powder. } \\
\text { No less than } 5 \mathrm{~kg} \text {. of earthworms' biomass is necessary to make } 1 \mathrm{~kg} \text {. of vermicompost. }\end{array}$ \\
\hline
\end{tabular}

These methods make it possible to get a high-quality protein product - animal feed. The most efficient method is the method of freeze-drying. It is the most expensive one 
since it requires special equipment and large amounts of electricity for industrial production.

Biological safety of vermipowder.

There can be some parasites typical both for humans and animals in earthworms, e.g. nematodes and protists. Parasitical organisms and different pathogens can be in earthworm's tissues especially in sacs. Earthworms grown in sewage sludge are a particular danger. Therefore, vermicompost should be sterilized.

Heavy metals and biocidal toxic substances found in substrates for earthworms' cultivation can be dangerous. Earthworms can accumulate some heavy metals: lead, copper, chromium, cadmium, nickel, mercury and zinc [8].

One of the ways of earthworms' tolerance to heavy metals is the induction of synthesis of specific metal-combining protein - molecular weight proteins high in cysteine. They can bind both physiologically essential metals (zinc, copper, selenium) and metals-xenobiotics (cadmium, mercury, silver, arsenic etc.). The binding of heavy metals is due to a thiol group of cysteine. Although the functions of metallothioneins have not been fully researched, they are considered important to protect from heavy metal intoxication. For example, high concentrations of cadmium induce earthworms' three cadmium binding protein synthesis [9].

\subsubsection{Packaging and storage of vermicompost}

Vermicompost is recommended to store in sealed plastic bags. The marking should contain detailed information about the product. The storage conditions: dry, cool place without direct sunlight. Shelf life is 6 months [7].

\subsection{Economic characteristics of vermiproducts}

The levels of bioconversion of different organic waste in earthworms' biomass make from 4 to $10 \%$ per dry matter. These are rather good indicators with high added value. Moreover, producers get $40-50 \%$ of organic fertilizer - vermicompost.

However, vermiproduction cannot be considered economically advantageous due to high technology-intensity and low price competitiveness compared with soybean flour and fish meal [2,3]. Vermipowder production and marketing can be promising if there are costeffective ways to make it.

The use of earthworms along with vermicompost is the simplest and cheapest way of making feed additives. For example, the cost of $1 \mathrm{~kg}$. dry mixture of earthworms $(6 \%)$, wheat middling and worm castings (105) is 0.26 yuan cheaper than fish meal. The use of this additive in poultry has enabled to get $0.03 \mathrm{~kg}$. more of egg production. The profit was 0.41 yuan $/ 1 \mathrm{~kg}$. feed. Poultry live weight increased and feed digestion was better (Sun, 2003).

The computer analysis of vermipowder economic value was based on the content of amino acids, fatty acids, macro- and microelements, vitamins: cattle $-130 £$ per ton; poultry: duck - 183-218; broiler $-220-249$, baby turkeys -1011 , turkeys $-338 £$ per ton; fish: trout -404 , eels $-2000 £$ per ton.

Despite many benefits concerning the use of vermipowder in raising different animals it is impossible to conduct a reliable assessment of vermicompost, vermipowder and vermipaste due to numerous unstable factors. 


\subsection{Fodder and nutritional value of vermiproducts}

\subsubsection{Vermiculture feeding value}

The first successful tests concerning animals' feeding with vermicompost were conducted on chickens and hog babes (Sabine, 1978). The main objective of such works is the estimation of nutritional value of feed protein; recommendations on growing different species of fish, poultry, pigs and rabbits; safety analysis and economic benefits of its use. The results achieved on the use of vermicompost are shown in table 3.

Table 3. Fodder alue of protein drugs from vermiculture

\begin{tabular}{|c|c|c|c|}
\hline Authors & $\begin{array}{l}\text { Vermiculture } \\
\text { products }\end{array}$ & Objects & Results \\
\hline \multicolumn{4}{|c|}{ Fish } \\
\hline $\begin{array}{l}\text { Stafford, Tacon, } \\
1983\end{array}$ & $\begin{array}{l}\text { Earthworms Eisenia } \\
\text { fetida, Allolobophora } \\
\text { longa, Lumbricus } \\
\text { terrestris }\end{array}$ & trout & $\begin{array}{l}\text { Frozen earthworms A. Longa и L. terrestris: } \\
\text { fish growth was the same or better; complete } \\
\text { ration consisting of sublimate earthworm } \\
\text { powder E. fetida: trout's growth was less } \\
\text { intensive }\end{array}$ \\
\hline Guerrero, 1983 & $\begin{array}{l}\text { Earthworm protein of } \\
\text { Perionixex cavatus, } \\
\text { Eudrilus eugeniae }\end{array}$ & tilapia & $\begin{array}{l}\text { Higher productivity compared to the use of } \\
\text { animal feed containing food tankage }\end{array}$ \\
\hline $\begin{array}{l}\text { Sogbesan et. al., } \\
2007[10]\end{array}$ & Vermipowder, 70 days & $\begin{array}{l}\text { fresh-water } \\
\text { catfish } \\
\text { fry }\end{array}$ & $\begin{array}{l}\text { Adding } 25 \% \text { of vermipowder gave a better } \\
\text { growth, higher doses led to a growth } \\
\text { inhibition. } \\
\text { Packed cell volume, hemoglobin and white } \\
\text { cell count increased in fry's blood. } \\
\text { There is the highest rates of return at the } \\
\text { lowest level of costs }\end{array}$ \\
\hline $\begin{array}{l}\text { Soghbesan и } \\
\text { Ugwumba, } 2008\end{array}$ & $\begin{array}{l}\text { tadpole, } \\
\text { termite } \\
\text { garden snails, } \\
\text { earthworms }\end{array}$ & Aquaculture & $\begin{array}{l}\text { There are significant differences concerning } \\
\text { the content of protein, fat and essential } \\
\text { amino acid. } \\
\text { Feed meal of } 4 \text { types can be used as } \\
\text { additives in fish meal in Nigeria. }\end{array}$ \\
\hline $\begin{array}{l}\text { Nekrasova et. } \\
\text { al., } 2007 \\
\text { Vasilyeva, } \\
\text { Nekrasova, } 2010\end{array}$ & $\begin{array}{l}\text { Paste like fodder }+ \\
\text { vermiculture }\end{array}$ & sturgeon & $\begin{array}{l}\text { Earthworms making } 10 \% \text { of paste like } \\
\text { fodder account for an average daily increase } \\
\text { in weight and length (of } 1.1 \text { times), fodder } \\
\text { cost reduction (of } 1.3 \text { times). }\end{array}$ \\
\hline $\begin{array}{l}\text { Lul'ko et. } \\
\text { al.,2008 }\end{array}$ & $\begin{array}{l}\text { Duckweat and } \\
\text { earthworm powder }\end{array}$ & Dietary fish & $\begin{array}{l}\text { There is a maximum preservation of hatched } \\
\text { larva; fish farming is based on dietary } \\
\text { properties and lead to a powerful immune } \\
\text { system. }\end{array}$ \\
\hline \multicolumn{4}{|c|}{ Poultry } \\
\hline $\begin{array}{l}\text { Harwood, } 1976 \\
\text { Sabine, } 1978 \\
\end{array}$ & $\begin{array}{l}\text { Vermipowder and } \\
\text { meat-meal }\end{array}$ & chickling & $\begin{array}{l}\text { The comparison of vermipower with meat- } \\
\text { meal has not revealed any difference. }\end{array}$ \\
\hline $\begin{array}{l}\text { Mekada et. al., } \\
1978\end{array}$ & $\begin{array}{l}\text { Vermipowder, soya } \\
\text { bean and fish meal }\end{array}$ & $\begin{array}{l}\text { Plymouth } \\
\text { Rock, } \\
\text { leghorn }\end{array}$ & $\begin{array}{l}\text { The comparison has not revealed any } \\
\text { difference concerning animal growth rate, } \\
\text { egg-laying capacity, egg weight and quality. }\end{array}$ \\
\hline $\begin{array}{l}\text { Jin-you et. al., } \\
1982\end{array}$ & Earthworms, fish meal & chickling & $\begin{array}{l}\text { There has been a high weight growth: bigger } \\
\text { pectoralis; less fodder consumption. }\end{array}$ \\
\hline Ton et. al., 2009 & $\begin{array}{l}\text { Earthworms Perionyx } \\
\text { excavatus }\end{array}$ & poultry & $\begin{array}{l}\text { Poultry growth rate has increased by } 10.6 \% \\
\text { along with lower fodder consumption (by } \\
10.6 \% \text { ) in a span of } 10 \text { weeks while adding } \\
1-2 \% \text { of earthworms. }\end{array}$ \\
\hline $\begin{array}{l}\text { Silvestre, } 1984 \\
\text { Dioson, } 1984 \\
\text { Setyo, } 2011 \\
\end{array}$ & $\begin{array}{l}\text { Vermipowder instead } \\
\text { of fish meal }\end{array}$ & $\begin{array}{l}\text { Japanese } \\
\text { quail }\end{array}$ & $\begin{array}{l}\text { Adding } 10 \% \text { of vermipowder has increased } \\
\text { the productivity and poultry growth rate. }\end{array}$ \\
\hline $\begin{array}{l}\text { Oliva and } \\
\text { Nikolaeva, } 2007 \\
{[11]}\end{array}$ & $\begin{array}{lr}\text { Vermicompost } & \text { with } \\
\text { earthworms } & \text { remains } \\
\text { and their cocoons } & \end{array}$ & $\begin{array}{l}\text { broiler } \\
\text { chicken }\end{array}$ & $\begin{array}{l}\text { The vermicompost rate of application } 2.5 \text { gr. } \\
\text { per one species a day in addition to the main } \\
\text { ration; feed intake is good; the increase in }\end{array}$ \\
\hline
\end{tabular}




\begin{tabular}{|c|c|c|c|}
\hline & & & $\begin{array}{l}\text { live weight is } 20 \% \text { higher; feed } \\
\text { consumption } 7 \% \text { lower for } 1 \mathrm{~kg} \text {. of gain } \\
\text { weight. }\end{array}$ \\
\hline $\begin{array}{l}\text { CJSC } \\
\text { "Rybnovskaya } \\
\text { poultry plant" } \\
\text { (Ryazan Oblast), } \\
2012\end{array}$ & $\begin{array}{l}\text { Vermicompost with } \\
\text { earthworms remains } \\
\text { and their cocoons }{ }^{2}\end{array}$ & $\begin{array}{l}\text { laying } \\
\text { chicken }\end{array}$ & $\begin{array}{l}\text { The vermicompost rate of application } 5-20 \\
\text { gr. per one species a day; } 8.5 \% \text { increase in } \\
\text { productivity; } 7.5 \% \text { decrease in cracked- } \\
\text { shell egg, reducing the specific feed cost } \\
\text { (per } 1000 \text { eggs) }-5.4 \% \text {. }\end{array}$ \\
\hline $\begin{array}{l}\text { Poultry Plant } \\
\text { «Ryazansky } \\
\text { Broiler», } 2011\end{array}$ & $\begin{array}{l}1.2 \% \text { of earthworm } \\
\text { Eisenia fetida (protein } \\
\text { deficiency } 6 \% \text { ) }\end{array}$ & $\begin{array}{l}\text { broiler } \\
\text { chicken }\end{array}$ & $\begin{array}{l}\text { Appearance: healthy, brightly-coloured } \\
\text { combs, distinct sex dimorphism, poultry } \\
\text { preservation and an increase in live weight } \\
\text { (higher } 24.6 \% \text { and } 16.2 \% \text { respectively); feed } \\
\text { costs have dropped by } 24 \% \text { per } 1 \mathrm{~kg} \text {. gain. }\end{array}$ \\
\hline \multicolumn{4}{|c|}{ Mammals } \\
\hline $\begin{array}{l}\text { Harwood, } 1976 \\
\text { Sabine, } 1978\end{array}$ & $\begin{array}{l}\text { Feed protein } \\
\text { earthworms }\end{array}$ & pigs & $\begin{array}{l}\text { On average, the gain is similar to the use of } \\
\text { commercial fodder and meat meal }\end{array}$ \\
\hline $\begin{array}{l}\text { Jin-you et. al., } \\
1982\end{array}$ & Earthworm protein & pigs & $\begin{array}{l}\text { Sows had an earlier oestrus, epiphylaixis, a } \\
\text { reduction in diarrhea incidence }\end{array}$ \\
\hline $\begin{array}{l}\text { Orozco et. al, } \\
1988\end{array}$ & $\begin{array}{l}\text { Earthworm protein of } \\
\text { Eisenia retida, } \\
\text { Lumbricus rubellus }\end{array}$ & rabbits & $\begin{array}{l}\text { The substitution of } 30 \% \text { soybean meal with } \\
\text { vermipowder does not affect rabbits' } \\
\text { growth. Vermipowder is similar to fish and } \\
\text { meat meal but is more nutritional than } \\
\text { soybean meal due to the amino acid supply } \\
\text { and protein digestion. }\end{array}$ \\
\hline \multicolumn{4}{|c|}{ Culture media for cultivating microorganisms } \\
\hline $\begin{array}{l}\text { Timchenko et. } \\
\text { al., } 2009\end{array}$ & $\begin{array}{l}\text { Culture media based } \\
\text { on } \\
\text { enzyme digest from } \\
\text { earthworm biomass }\end{array}$ & $\begin{array}{l}\text { cultivation of } \\
\text { microorganis } \\
\mathrm{ms}\end{array}$ & $\begin{array}{l}\text { Hydrolysate contains organic acids, essential } \\
\text { amino acids, vitamins PP, A, C, } \mathrm{B}_{1}, \mathrm{~B}_{2} \text { ), } \\
\text { macro- and microelements, carbohydrates; it } \\
\text { can replace culture media based on beef and } \\
\text { sprats. It has certain advantages: high } \\
\text { quality, low prices and a broad sphere of } \\
\text { application. }\end{array}$ \\
\hline
\end{tabular}

Note: 1 - Compost composition (per dry matter): nitrogen $-1.5-2.5 \%$, phosphorus $-1.0-2.0 \%$, potassium $-2.8 \%$, cobalt $-2.0 \mathrm{мг} / \mathrm{\kappa г}$, manganese $-80 \mathrm{mg} / \mathrm{kg}$, iron $-245 \mathrm{mg} / \mathrm{kg}$, zinc $-105 \mathrm{mg} / \mathrm{kg}$, copper $-24.0 \mathrm{mg} / \mathrm{kg}$. Biomass composition (per dry matter): mass fraction of crude protein $57.3 \pm 2.4$; crude fat $-10.6 \pm 1.2$; crude ash $-10.3 \pm 0.1$; free-nitrogen extract $-21.8 \pm 0.3 \%$. Mineral composition of biomass: mass fraction of calcium $-0.7 \pm 0.12$; phosphorus $-0.4 \pm 0.01 \%$; iron $-1300.0 \pm 50.0$; manganese $-21.0 \pm 5.4$; zinc $-435.0 \pm 15.8$; copper $-14.0 \pm 2.4$; iodine $-0.6 \pm 0.3 \mathrm{mg} / \mathrm{kg}$.

2 - Vermicompost composition: nitrogen $-2.75 \%$, phosphorus $-2.4 \%$, calcium $-3.2 \%$, humic substance $-10.4 \%$, cobalt - $2 \mathrm{mg} / \mathrm{kg}$, copper- $25 \mathrm{mg} / \mathrm{kg}$, manganese $-88 \mathrm{mg} / \mathrm{kg}$, iron $-215 \mathrm{mg} / \mathrm{kg}$.

\subsubsection{Vermiculture nutritional value}

People have been eating earthworms since ancient times especially in tropical countries where nowadays earthworms are the main source of protein [12].

Walles reported on including insects and earthworms into the diet of Indians in the province Rio Negro (Brazil) [13]. Yekuana Indians (southern Venezuela) consider some species of earthworms extremely essential in their diet. They gather earthworms Glossoscolecidae, including the white earthworm called by locals "motto", that can be found in the mud of streams and rivers. They also gather quite a large species called "kuru" which inhabits the mountain forest floor. Indians eat these earthworms either raw or after being heated in water at the temperature of $60-80{ }^{\circ} \mathrm{C}$ or after being boiled. A smoked product is considered a delicacy and has great commercial value. It is three times more expensive than smoked fish, game, pork and chicken. According to Yekuana Indians' tradition, a woman must have such food as manioca and earthworms in the first month after giving birth. 
Biochemical research of vermifoods cooked from motto and kuru earthworms into their content of 18 amino acids, 9 saturated fatty acids, monounsaturated fatty acids, 11 polyunsaturated fatty acids and 20 macro- and microelements has revealed that these foods contain a large amount of total protein (64.5-72.9\% per dry weight), all essential amino acids, omega-3, polyunsaturated fatty acids (linoleic, linolenic, arachidonic and docosahexaenic). The calcium content was similar to its content in cheese and milk, iron 10 times more than in soybeans [13].

The inhabitants of Fujian, Hainan and Guangdong Provinces (China) eat earthworms. The local population on Taiwan cook special dishes which main ingredient is earthworms.

New Zealand's indigenous people Maori, aborigines of Australia and Papua New Guinea use earthworms and insects as a source of food. Some of them are spirit animals [12].

Cayot conducted the research of powder from earthworms as a dietary supplement. It has been proved that pancakes of satisfactory quality have been made from corn flour with the addition of $5.5 \%$ of vermipowder. The use of a special sensory analysis has made it possible to reveal 70 compounds such as ketones, spirit and aldehydes accounting for unpleasant odor of vermipowder. Partial vermipowder defating has improved its organoleptic characteristics [14].

\section{Conclusion}

The large-scale production earthworms' biomass and the use of this renewable bioresource for the production of high-quality fodder premixes and foods is promising research and practice.

The Food and Agriculture Organization of the UN submitted a report "Edible Insects: Future Prospects for Food and Feed Security" at the international conference devoted to the role of forests in food safety and nutrition (Rome, 13-15 May, 2013). According to the report, eating some invertebrate animals including earthworms can contribute to the fight against global hunger and improve the health standards around the world making up the deficiency in protein and reducing environmental pollution. It focused on the idea of entomological farming as a source of animal feed and food for the human population.

\section{References}

1. G.A. Dedeke, S.O. Owa, K.B. Olurin, Agriculture and Biology Journal of North America, 1(2), 97 (2010)

2. C.A. Edwards, A. Niederer, Vermiculture Technology: Earthworms, Organic Wastes, and Environmental Management, 323 (2011)

3. C.A. Edwards, N.Q. Arancon, In Earthworm Ecology, 345 (2004)

4. E.V. Antonova, International Conference on Construction, Architecture and Technosphere Safety, 451, 1 (2018)

5. O.V. Irikov, J.I. Zadutskij, The patent of Russia № 2011105477 from 14.02 .2011 (2011)

6. B.B. Kuznetsov, Aksenov A.V., Kozintsev A.L., R.V. Ulanova, The patent of Russia № 2283000 from 19.11.2003 (2003)

7. R.D. Guerrerro, MARID Agribusiness Technology Guide, 22 (2009)

8. A.J. Morgan, Vermiculture Technology: Earthworms, Organic Wastes, and Environmental Management, 263 (2011) 
9. S.H. Liang, S.C. Chen, C.Y. Chen, C.M. Kao, J.I. Yang, B.C. Shieh, J.H. Chen, C.C. Chen, Pedobiologia, 54(5-6), 333 (2011)

10. O.A. Sogbesan, A.A.A. Ugwumba, C.T. Madu, S.S. Eze, J. Isa, Journal of Fisheries and Aquatic Science, 2, 375 (2007)

11. T.V. Oliva, I.V. Nikolaeva, Advances in modern natural science, 12, 33 (2007)

12. E.L. Cooper, Hirabayashi K., M. Dalamtnurugan, Tradition and Complementary Medicine, 2(4), 242 (2011)

13. V.G. Paoletti, E. Buscardo, D.J. VanderJagt, A. Pastuszyn, L. Pizzoferrato, Y.-S. Huang, L.-T. Chuang, M. Millson, H. Cerda, F. Torres, R.H. Glew, Proc.R.Soc.Lond., 270, 249 (2003)

14. N. Cayot, P. Cayot, E. Bou-Maroun, H. Laboure, B. Abad-Romero, K. Pernin, N. Seller-Alvarez, A.V. Hernández, E. Marquez, Internat. J. Food Sci. \& Tech., 44(11), 2303 (2009)

15. I.N. Titov, V.M. Usoev, Tomsk State University Journal of Biology, 2(18), 74 (2012) 